\title{
Pengaruh Psikologi Gestalt dalam Mengantisipasi Miskonsepsi Matematika
}

\author{
Aliya Fitrahani \\ Institut Agama Islam Negeri Kudus \\ aliyafitrahani@gmail.com
}

\begin{tabular}{l}
\hline \hline Article Info \\
\hline Article history: \\
Received April, $15^{\text {th }} 2021$ \\
Revised June $10^{\text {th }}, 2021$ \\
Accepted July $22^{\text {th }}, 2021$ \\
\\
\hline
\end{tabular}

Keywords:

Gestalt Psychology;

Misconceptions;

Mathematics

\begin{abstract}
This article discusses the importance of understanding concepts in the learning process whose peak can anticipate the occurrence of misconceptions in mathematics. The purpose of this study is to link mathematics learning with the psychological condition of students. Gestalt psychology says that learning is not just accumulating knowledge, but learning is a process of interaction between the individual and his environment. The research method uses a literature study by raising issues from Gestalt Psychology about meaning, understanding, and insight. The results of this study indicate that through the ability of insight, students are expected to be able to relate learning to everyday life, especially in Mathematics subjects where at the peak students are able to solve mathematical problems by understanding their own concepts, which in turn can anticipate all forms of misconceptions in mathematics.
\end{abstract}

\author{
Kata Kunci: \\ Psikologi Gestalt; \\ Miskonsepsi; \\ Matematika
}

\begin{tabular}{l} 
Abstrak \\
Artikel ini membahas tentang pentingnya pemahaman \\
konsep dalam proses belajar yang puncaknya dapat \\
mengantisipasi terjadinya miskonsepsi dalam \\
matematika. Tujuan dari penelitian ini berusaha \\
mengaitkan pembelajaran matematika dengan kondisi \\
psikologis siswa. Psikologi Gestalt berbicara bahwa \\
pembelajaran bukan hanya sekedar menumpuk \\
pengetahuan, melainkan pembelajaran merupakan \\
sebuah proses interaksi antara indvidu dengan \\
lingkungannya. Metode penelitian menggunakan studi \\
literatur dengan mengangkat isu dari Psikologi Gestalt \\
soal makna, pemahaman, dan wawasan. Hasil dari \\
penelitian ini menunjukkan bahwa melalui kemampuan \\
insight, peserta didik diharapkan mampu mengaitkan \\
pembelajaran dengan kehidupan sehari-hari, khususnya \\
\hline
\end{tabular}


dalam mata pelajaran matematika yang puncaknya peserta didik mampu menyelesaikan persoalan matematika dengan pemahaman konsepnya tersendiri, yang selanjutnya mampu mengantisipasi segala bentuk miskonsepsi dalam matematika.

\section{PENDAHULUAN}

Belajar merupakan suatu proses dimana suatu organisasi berubah perilakunya sebagai akibat dari pengalaman (Gagne, 1984). Definisi singkat terkait proses belajar mengajar adalah aktivitas antara pendidik dengan peserta didiknya dalam mengeksplorasi sebuah pengalaman baru (Herna 2014). Belajar menyangkut perubahan setiap individu, hal ini diartikan bahwa belajar adalah sebuah proses. Mayoritas masyarakat menilai bahwa belajar merupakan basis untuk tercapainya kemajuan masyarakat di masa yang akan datang. Mengingat pentingnya belajar bagi masyarakat dan tiap individu, diperlukan sistem pengajaran yang mampu mempersiapkan generasi muda untuk mengambil alih peran dan bersikap produktif. Karenanya, sistem Pendidikan formal dimaksudkan untuk menangani pengetahuan dan keahlian khusus yang dipilih oleh individu untuk dipelajari lebih mendalam.

Khairuzzaman menyatakan bahwa pembelajaran diartikan lebih dari sekedar proses menumpuk pengetahuan dan hafalan, tetapi pengetahuan yang diperoleh siswa harus lebih bermakna mealui kemampuan berpikir (Khairuzzaman, 2016). Hal ini berbanding terbalik dengan sistem pembelajaran di Indonesia. Pembelajaran sering diartikan sebagai mentransfer pengetahuan tanpa mengetahui dengan jelas apa maksud dan tujuan dari pembelajarannya sendiri. Hal ini mengakibatkan hilangnya makna dari sebuah pembelajaran, serta peserta didik kurang bisa merasakan manfaat dari belajar yang kemudian menjadikan diferensiasi minat terhadap belajar.

Permasalahan umum yang dapat diamati penulis secara langsung adalah dalam proses pembelajaran matematika. Pembelajaran matematika yang diberlakukan hanyalah sekedar pemberian materi singkat, kemudian menjawab soal dengan rumus. Hal ini mengakibatkan pembelajaran terasa 
monoton dan kurang dipahami oleh siswa. Di sisi lain, pembelajaran matematika dinilai oleh sebagian siswa merupakan mata pelajaran yang sulit dan bersifat abstrak karena banyaknya simbol dan lambang yang selanjutnya malah menghilangkan minat peserta didik. Pemikiran peserta didik haruslah dikonstruksikan agar mereka mampu memahami konsep pelajaran dan menjadikan pembelajran lebih bermakna. Oleh karena itu, diperlukan strategi inovatif yang mengacu pada teori-teori pembelajaran. Salah satunya adalah Psikologi Gestalt.

Psikologi Gestalt menilai bahwa pembelajaran merupakan sebuah proses, bukan menghafal. Aktivitas setiap individu juga berkenaan dengan lingkungannya. Melalui interaksi itulah yang membentuk suatu wawasan atau pemahaman atau yang sering disebut dengan insight (Hidayati et al., 2020) Psikologi Gestalt menitikberatkan peran aktif dalam pembelajaran adalah dari peserta didik, sehingga guru hanya sebagai fasilitator yang membimbing peserta didik agar mampu merekontruksikan matematika dalam bentuk sederhana dan mengaitkan konsep matematika dalam kehidupan sehari-hari. Memandang kenyataan ini, Psikologi Gestalt dinilai layak untuk dijadikan pedoman dalam pembelajaran matematika, terutama dalam mengantisipasi terjadinya miskonsepsi dalam matematika dan untuk menumbuhkan minat peserta didik terhadap matematika. Penelitian relevan dilakukan oleh Richa Aulya dan Jayanti Purwaningrum dengan judul Penerapan Teori Gestalt dalam Materi Luas dan Keliling Bangun Datar untuk SD/MI. Dalam penelitian tersebut membahas tentang pengaplikasian Teori Gestalt pada pembelajaran luas dan keliling bangun datar dengan penemuan rumus yang berangkat dari proses interaksi dengan lingkungan. Selanjutnya, hal yang sama juga dikatakan oleh Agustina Hariani Panjaitan dan Edy Surya dalam penelitiannya yang berjudul Berpikir Kreatif dalam Pembelajaran Matematika, penelitian tersebut mengungkapkan bahwa salah satu hal yang paling berdampak pada proses belajar mengajar dan kemampuan berpikir kreatif siswa adalah belajar dari psikologis siswa sendiri. Psikologi Gestalt berusaha memfokuskan perhatiannya terhadap proses saat terjadinya pengertian dan persepsi pada manusia. Berangkat dari penelitian tersebut, maka kemudian penulis tertarik untuk melakukan 
penelitian lebih lanjut mengenai pengaruh Psikologi Gestalt dalam mengantisipasi miskonsepsi siswa saat belajar matematika.

\section{METODE PENELITIAN}

Subjek yang digunakan dalam penelitian adalah siswa kelas 9 Sekolah Menengah Pertama. Metode yang digunakan dalam penelitian ini menggunakan metode studi literatur dimana penulis mengumpulkan literatur terkait hal-hal yang menjadi permasalahan dalam matematika pada siswa, khususnya tentang psikologi anak dalam menerima pelajaran matematika. Sumber literatur penulis berasal dari buku, buku elektronik, jurnal, dan website online. Kajian teoritis dipelajari dengan baik oleh penulis untuk mendapatkan informasi terkait hal yang mengakibatkan miskonsepsi matematika pada siswa. Selain itu, peneliti juga melakukan observasi berupa percobaan dan demonstrasi guna mengetahui seberapa jauh pemahaman siswa dalam materi keliling bangun datar. Hasil observasi tersebut kemudian dikolaborasikan dengan penelitian relevan dan diuraikan dalam bentuk deskriptif kualitatif yang masih merujuk pada permasalahan untuk menarik sebuah kesimpulan.

\section{HASIL PENELITIAN DAN PEMBAHASAN \\ Psikologi Gestalt dalam Matematika}

Pengetahuan merupakan suatu usaha sadar mulai dari membimbing, mengajar, dan melatih peserta didik dengan tujuan tercapainya kesesuaian antara pribadi peserta didik dengan lingkungannya. Dari hal tersebut, diperlukan guru yang memiliki kompeten yang mampu merangkul peserta didik agar mampu mempermudah proses pembelajaran baik komunikasi maupun pemahaman konsep pembelajaran, terutama dalam bidang matematika. Pada dasarnya, pembelajaran matematika memerlukan sistem belajar yang lebih ekstra. Mengingat hal tersebut, dibutuhkan strategi mengajar yang matang, seperti psikologi kognitif. Psikologi kognitif menekankan bahwa yang paling penting dalam sebuah pembelajaran adalah bagaimana proses tersebut terjadi daripada mementingkan hasil. Salah satu teori yang membahas tentang psikologi kognitif adalah Teori Gestalt. 
Psikologi Gestalt memandang bahwa pengetahuan baru atau sebuah konsep merupakan sebuah masalah bagi anak yang strukturnya terorganisir. Psikologi Gestalt memfokuskan bidang kajiannya pada persepsi dalam belajar. Selain itu, Psikologi Gestalt memberikan konstribusi berupa konsep-konsep untuk memahami pemecahan masalah. Isu yang diambil oleh Gestalt ialah seputar makna, pemahaman, dan wawasan yang merupakan karakteristik dasar manusia (Wertheimer, 1991). Teori ini mempunyai sejumlah prinsip yang bisa dibilang layak untuk dijadikan sebuah pedoman dalam mengajar, yaitu:

1. Belajar berdasarkan keseluruhan

Setiap individu berusaha mencari hubungan antara materi yang satu dengan materi yang lainnya.

2. Belajar adalah suatu proses perkembangan

Materi yang baru akan bisa diterima dan dipahami dengan baik oleh seorang individu apabila ia telah memahami dengan matang materi sebelumnya, serta cukup matang untuk menerimanya. Dalam hal ini, pengalaman tiap individu sangat mempengaruhi kematangan individunya.

3. Siswa sebagai subyek organisme keseluruhan

Emosional dan fisik setiap individu turut terlibat selama proses belajar. Jadi, tidak hanya tentang intelektual saja.

4. Transfer

Tujuan dari belajar adalah supaya terjadi timbal balik antara peserta didik dengan pendidiknya, yang puncaknya adalah adanya respon yang tepat dalam suatu situasi tertentu. Apabila satu kemampuan yang telah diberikan mampu dikuasai dengan baik, maka dapat diteruskan pada kemampuan lainnya.

5. Belajar adalah reorganisasi pengalaman

Proses belajar mampu dikatakan terjadi bila individu mengalami situasi yang dirasa baru. Dalam hal ini, pengalaman yang telah dikuasai sangat membantu untuk menghadapi situasi baru.

6. Belajar dengan insight

Insight (wawasan) sangat berperan dalam memahami hubungan antara unsur-unsur yang ada pada sebuah masalah. 
7. Adanya minat, keinginan, dan tujuan belajar Adanya minat, keinginan, dan tujuan dalam belajar menjadi salah satu tolok ukur berhasilnya proses belajar. Namun, hal ini masih merujuk pada hal apa saja yang diperlukan setiap individu dalam kesehariannya, sehingga terdapat manfaat yang bias dirasakan dari hasil belajarnya

8. Kontinuitas belajar

Proses belajar terjadi baik di sekolah maupun di luar sekolah. Selain itu, belajar juga diperoleh dari pengalaman-pengalaman individu.

Prosedur pembelajaran menurut teori ini adalah pendidik secara tidak langsung membimbing peserta didiknya agar mampu menganalisis setiap penyelesaian suatu masalah berdasarkan struktur yang dirancang lebih sederhana dan telah dipahami oleh peserta didik sendiri. Kemudian, peserta didik mampu mengaplikasikan konsep yang telah dipahaminya. Dengan menimbang bahwa pembelajaran adalah sebuah konsep, hal ini akan memudahkan bagi siswa dalam mendefinisikan arti sederhana dari pembelajaran, khususnya matematika.

\section{Miskonsepsi Matematika}

Pembelajaran matematika kerap dianggap sebagai sebuah hal yang abstrak, karena banyaknya penggunaan simbol atau lambang. Melihat simbol-simbol yang belum dikenal sebelumnya, memicu emosi negatif dalam diri peserta didik yang kerap kali menghalangi pembelajaran efektif. Selain itu, pembelajaran matematika juga kerap dianggap sebagai penyelesaian soal dengan menggunakan rumus, bukan konsep. Sehingga sebagian besar dari siswa tidak dapat mendefinisikan dengan jelas atau menarik kesimpulan dari konsep dasar matematika. Pembelajaran matematika memerlukan pemahaman yang matang sebelum menerima materi yang baru. Hal ini senada dengan Psikologi Gestalt yang memandang bahwa matematika adalah proses belajar, bukan menghafal. Proses belajar merupakan fenomena kognitif. Teori Gestalt memiliki prinsip bahwa belajar merupakan suatu proses perkembangan materi baru yang bisa diterima maupun dipahami dengan baik jika individu tersebut telah memiliki kesiapan cukup matang untuk menerimanya. 
Permasalahan umum yang kerap menjadi perbincangan dalam matematika adalah banyaknya penggunaan rumus yang kurang dipahami oleh siswa. Salah satu bentuk permasalahannya dapat ditemukan dalam konsep bangun datar. Mayoritas dari guru matematika lebih mengaplikasikan rumus dalam penyelesaian sebuah soal, dibanding memilih untuk menjawab soal menggunakan definisi. Hal ini wajar jika peserta didik menemui soal yang dikategorikan LOTS (Lower Order Thinking Skills), namun penyelesaian soal menggunakan rumus kadang kerap mengakibatkan miskonsepsi matematika jika peserta didik kurang memahami konsep pendefinisian, terlebih jika peserta didik menemui soal dengan kategori HOTS (Higher Order Thinking Skills) yang terbilang menjadi tolak ukur intelegensi dalam Ujian Nasional. Miskonsepsi sendiri terjadi karena peserta didik cenderung lebih sering mendasarkan berpikirnya pada hal-hal yang tampak dalam sebuah penyelesaian masalah. Suparno (2013) menyatakan indikator miskonsepsi adalah konsep awal yang salah, kesalahan konsep, hubungan yang tidak benar diantara konsepkonsep, gagasan intuitif atau pandangan naif (yang tidak berpengalaman).

Psikologi Gestalt berbicara bahwa pembelajaran haruslah bermula dari pemaparan suatu masalah yang bertautan dengan konsep yang akan diberikan yang melingkup lingkungan sehari-hari. Ketika menginterpretasi sebuah konsep, peserta didik sebaiknya diberikan kesempatan yang leluasa untuk berdiskusi dalam memecahkan suatu masalah dengan temantemannya, ataupun dengan guru. Selain itu, pendidik juga diharapkan mampu membimbing peserta didik untuk aktif bereksplorasi, dan bereksperimen.

\section{Aplikasi Psikologi Gestalt dalam Pemahaman Konsep Keliling Persegi Panjang}

Berikut merupakan contoh model setting pembelajaran menurut Psikologi Gestalt dalam memahami konsep keliling persegi panjang adalah sebagai berikut:

1. Pendidik menginstruksikan kepada peserta didiknya untuk mengukur ruangan kelas yang berbentuk persegi panjang. 
2. Peserta didik menemukan masalah bagaimana cara mencari keliling ruangan kelas. Karena di meja guru terdapat sebuah meteran, maka timbul pengertian bahwa untuk mencari keliling, peserta didik harus mengukur sisi ruangan kelas dengan mengelilinginya.

3. Peserta didik mengukur ruangan kelas dan didapatkan sisi samping kelas adalah $9 \mathrm{~cm}$ sedangkan sisi depan dan belakang adalah $16 \mathrm{~cm}$.

4. Peserta didik menjumlahkan seluruh hasil penelitiannya, yaitu:

$$
\begin{aligned}
\text { Keliling } & =9+16+9+16 \\
& =(9+9)+(16+16) \\
& =(2 \times 9)+(2 \times 16) \\
& =2(9+16) \\
& =2 \times 25 \\
& =50
\end{aligned}
$$

Berdasarkan hal tersebut, peserta didik mampu menarik kesimpulan berdasarkan mengukur kelas tersebut didapatkan rumus untuk mencari keliling sebuah persegi panjang adalah $2 x$ (panjang + lebar). Permasalahan ini senada dengan penelitian Wolfgang Kohler yang menguji seekor kera harus menemukan solusi untuk meraih seiris pisang yang diletakkan di sisi luar kandang. Dalam studinya, ada problem "tongkat", dan seekor kera harus menggunakan tongkat panjang untuk mencapai seiris pisang.

Berdasarkan pengamatan di atas, siswa dituntut untuk memahami dengan betul apa yang menjadi konsep dalam sebuah permasalahan keliling bangun datar, sehingga siswa akan siap menerima materi baru yang akan diberikan oleh peserta didik. Kesiapan ini berdampak besar untuk mengantisipasi miskonsepsi dalam pemahaman konsep kelilng bangun datar. Contoh permasalahannya sebagai berikut:

\section{Masalah:}

Jika diketahui panjang DE $2 \mathrm{~cm}$, maka berapa keliling bangun pada Gambar 1 berikut? 


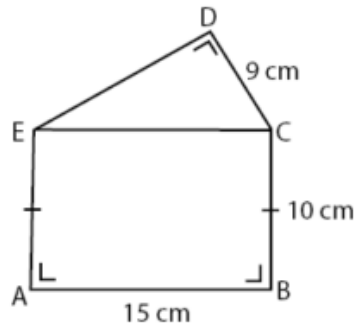

\section{Gambar 1. Bangun ABCDE}

Tujuan: Menguji apakah peserta didik telah siap terhadap materi yang baru berdasarkan prinsip Gestalt.

\section{Pembahasan:}

Penyelesaian soal tersebut cukup mengecoh peserta didik jika peserta didik belum sepenuhnya memahami materi. Salah satu dugaan kekhawatiran terhadap peserta didik dalam menyelesaikan soal ini adalah jika peserta didik langsung menerapkan rumus dengan menjumlahkan keliling persegi panjang dan keliling segitiga siku-siku. Jika hal tersebut dilakukan, akan menimbulkan miskonsepsi matematika yang berakibat fatal terhadap proses pemahaman, juga hasil pengerjaannya. Berikut salah satu penyelesaian karena miskonsepsi matematika:

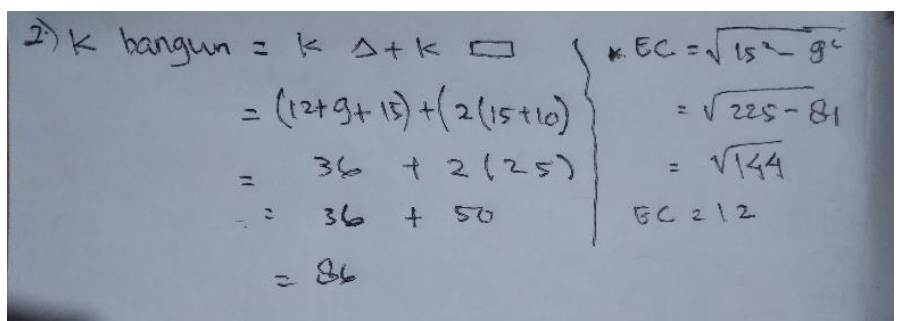

\section{Gambar 2. Hasil Pekerjaan Siswa}

Berangkat dari Teori Gestalt yang menekankan bahwa belajar merupakan proses kognitif, penyelesaian soal di atas dapat diselesaikan jika peserta didik telah memahami materi pendefinisian dari sebuah keliling bangun, yaitu menjumlahkan seluruh sisi tepi pada bangun tersebut. Penyelesaian yang didapat adalah sebagai berikut: 


\section{Mencari panjang DE dengan rumus Phytagoras:}

Diketahui $\mathrm{AB}=\mathrm{EC}$, maka:

$D E=\sqrt{E C^{2}-C D^{2}}$

$D E=\sqrt{15^{2}-9^{2}}$

$D E=\sqrt{225-81}$

$D E=\sqrt{144}$

$D E=12 \mathrm{~cm}$

Berdasarkan konsep, keliling merupakan penjumlahan semua sisi tepi, sehingga kemudian didapatkan keliling bangun tersebut sebagai berikut:

$\mathrm{K}=\mathrm{AB}+\mathrm{BC}+\mathrm{CD}+\mathrm{DE}+\mathrm{EA}$

$\mathrm{K}=15+10+9+12+10$

$\mathrm{K}=56 \mathrm{~cm}$

Dengan demikian, penerapan rumus memerlukan pemahaman konsep yang matang dari definisi. Hal mendasar dari Teori Gestalt adalah proses belajar dari pemahaman konsep yang kemudian akan menimbulkan pemikiran produktif pada peserta didik dalam menanggapi sebuah permasalahan.

Berpikir produktif merupakan pemahaman murni tentang hakikat dari suatu problem yang berasal murni dari individu tanpa paksaan orang lain. Jika seorang peserta didik mampu berpikir produktif, hal ini akan berdampak baik bagi ingatan memori mereka yang nantinya akan diingat dengan jangka waktu yang lama. Dalam hal ini, Wertheimer mengungkapkan pendekatan terhadap penekanan tentang pentingnya logika, baik berupa logika induktif maupun logika deduktif yang tetap mengacu kaidah untuk mendapatkan kesimpulan. Dalam mendapatkan pemahaman ini akan melibatkan beberapa aspek dari pribadi peserta didik, seperti kecerdasan, sikap, emosi, dan depresi. Selanjutnya, pendekatan yang digunakan ialah prosedur yang didasarkan pada doktrin asosionisme. Contohnya:

1. Peserta didik diperkenalkan materi persegi panjang, kemudian bisa diajari tentang cara menghitung luas persegi panjang. 
2. Selanjutnya, peserta didik dihadapkan dengan jajar genjang, kemudian peserta didik diinstruksikan untuk menghitung luas dari jajar genjang tersebut berdasarkan pada pemahaman konsep persegi panjang.

3. Peserta didik yang sebelumnya telah belajar tentang menghitung luas persegi panjang, kemudian menarik garis tegak lurus sedemikian sehingga akan membentuk sebuah segitiga. Segitiga tersebut nantinya akan dipotong dan digabungkan ke sisi sebelahnya, sehingga membentuk bangun persegi. Kemudian, peserta didik mampu menghitung luasnya dengan mengalikan panjang dan lebarnya. Peserta didik yang melakukan hal tersebut akan mampu memecahkan masalah daripada peserta didik yang tidak bereksperimen atau tidak memiliki pengetahuan seperti ini.

Dari hal tersebut, Wertheimer menekankan poin yang serupa, yakni belajar yang didasari oleh pemahaman akan lebih dalam dan lebih dapat digeneralisasikan daripada belajar yang hanya didasari oleh hafalan tanpa pemahaman. Namun dalam hal ini, peserta didik harus melihat dengan benar apa yang menjadi hakikat atau struktur dari permasalahan. Contoh lain adalah dalam penerapan konsep keliling bangun datar berikut.

Masalah: Berapa keliling bangun pada Gambar 3?

Tujuan: Menguji tingkat berpikir produktif pada peserta didik

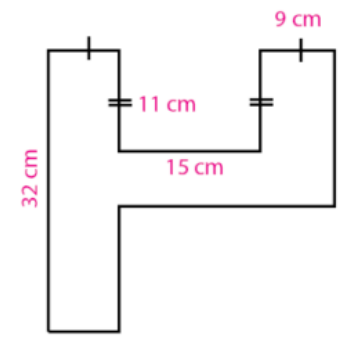

\section{Gambar 3}

\section{Pembahasan:}

Berpikir produktif akan memudahkan peserta didik dalam menjawab soal. terkait soal di atas, perhitungan akan lebih mudah dilakukan jika melihat dengan sudut pandang yang berbeda. Perhatikan gambar berikut: 


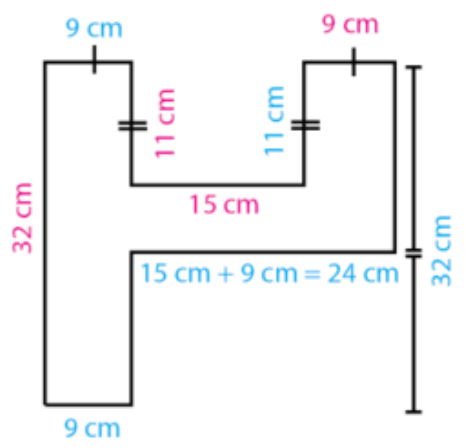

Gambar 4

Ukuran tersebut didapatkan dari pemikiran produktif bahwa sisi persegi panjang memiliki dua simetri yang sama. Sehingga keliling bangun tersebut adalah

$$
\begin{aligned}
\mathrm{K} & =32+9+24+32+9+11+15+11+9 \\
& =152
\end{aligned}
$$

Pengamatan di atas berusaha menghubungkan konsep mulai dari definisi, pengantisipasian miskonsepsi, dan berpikir kreatif. Keseluruhan dari konsep ini akan berdampak baik pula pada kontinuitas ingatan peserta didik dalam memahami konsep pembelajaran. Salah satu teoretis Gestalt, yaitu Kurt Koffka, berusaha menghubungkan antara masa lalu dengan masa sekarang lewat sebuah konsep memory face (jejak memori). Jejak ingatan merupakan suatu pengalaman yang mampu membekas di pikiran setiap manusia, kemudian diorganisasikan secara runtut berdasar pada prinsip-prinsip Psikologi Gestalt, yang kemudian akan teringat kembali ketika kita mempersepsikan suatu hal yang dinilai serupa. Misalnya dalam memecahkan suatu masalah, maka solusinya akan melekat dalam pikiran individu (jejak memori). Hal demikian, berpengaruh besar terhadap kualitas memori jangka panjang pada setiap individu.

\section{SIMPULAN}

Psikologi Gestalt memandang bahwa pengetahuan baru atau sebuah konsep merupakan sebuah masalah bagi anak yang strukturnya terorganisir, sehingga teori ini mengantisipasi terjadinya miskonsepsi pada suatu pembelajaran, khususnya matematika. miskonsepsi terjadi karena 
kurang siapnya peserta didik dalam memahami suatu permasalahan serta kurang mendalami pemahaman konsep pembelajaran. Psikologi Gestalt memfokuskan bidang kajiannya pada persepsi dalam belajar. Belajar didefinisikan sebagai sebuah proses, bukan menghafal. Pemahaman konsep menurut Psikologi Gestalt bermula dari definisi, pengantisipasian miskonsepsi, dan berpikir kreatif. Keseluruhan dari konsep ini akan berdampak baik pula pada kontinuitas ingatan peserta didik dalam memahami konsep pembelajaran karena pemahaman konsep berpengaruh besar terhadap kualitas memori jangka panjang pada setiap individu.

\section{DAFTAR PUSTAKA}

Amir, Zubaidah dkk. (2015). Psikologi Pembelajaran Matematika. Aswaja Pressindo. Diakses di http://repository.uinsuska.ac.id/10388/1/Psikologi\%20Pembelajaran\%20Matematika.pdf.

Id School. (2021). "Contoh Soal Segiempat dan Segitiga Matematika SMP”. Diakses di https://idschool.net/contoh-soal-segiempat-dansegitiga-matematika-smp-1/.

Gredler, Margaret E. (2011). Learning and Instruction: Teori dan Aplikasi, Edisi Ke-6. Terjemahan dari Tri Wibowo B.S. Jakarta: Prenada Media Group.

Safitri, Nila. (2020). Ruang Ketik Mahasiswa: Aplikasi Teori Gestalt sebagai Pedoman Mengajar dalam Pendidikan Matematika. PT. Nasya Expanding Management. Diakses di https://books.google.co.id/books?hl=id\&lr=\&id=jqwEEAAAQBAJ\& oi=fnd\&pg=PA77\&dq=teori+belajar+gestalt+dalam+pembelajaran+ matematika\&ots=eNGOwUejg5\&sig=iGcEjptZQBW175VhJxxUU WbutS4\&redir_esc=y\#v=onepage $\& \mathrm{q}=$ teori $\% 20$ belajar $\% 20$ gestalt $\% 2$ 0dalam\%20pembelajaran\%20matematika\&f=false.

You're Dreams. (2021). "Teori Belajar Gestalt dalam Pembelajaran Matematika". Diakses di http://aizzaturrohmahmath.blogspot.com/2016/01/teori-belajargestalt-dalam.html. 
76 | Fitrahani: Pengaruh Psikologi Gestalt dalam Mengantisipasi Miskonsepsi Matematika

Airiza, Yulia. (2021). "Teori Gestalt". Diakses di http://staffnew.uny.ac.id/upload/131656353/pendidikan/h-2-teorigestalt-revisi.pdf. 